ISSN: $1410-8917$

Jurnal Kimia

Sains \& Aplikasi
Jurnal Kimia Sains dan Aplikasi Journal of Scientific and Applied Chemistry

Journal homepage: http://ejournal.undip.ac.id/index.php/ksa

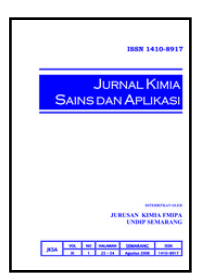

\title{
Isolasi, Identifikasi dan Uji Aktivitas Antibakteri Minyak Atsiri Akar Sidaguri (Sida rhombifolia Linn)
}

\author{
Winarti $^{\mathrm{a}}$, Dewi Kusrini ${ }^{*}{ }^{*}$, Enny Fachriyah ${ }^{\mathrm{a}}$ \\ a Organic Chemistry Laboratory, Chemistry Department, Faculty of Sciences and Mathematics, Diponegoro University, Jalan Prof. \\ Soedarto, Tembalang, Semarang 50275 \\ * Corresponding author: dewi.kusrini@live.undip.ac.id
}

\begin{tabular}{|c|c|}
\hline Article Info & Abstract \\
\hline & Isolation, identification and antibacterial activity test of the roots (Sida rhombifolia Linn) \\
\hline $\begin{array}{l}\text { Keywords: } \\
\text { antibacterial, } \\
\text { essential oil, Sida } \\
\text { rhombifolia Linn. }\end{array}$ & $\begin{array}{l}\text { essential oil was carried out. The purposes of this research were to isolate and identify } \\
\text { components of essential oil from Sida rhombifolia L. root and to find out of antibacterial } \\
\text { activity from it's essential oil. The methods used in this research are steam distillation, } \\
\text { brine shrimp lethality test (BSLT), Gas Chromatography-Mass Spectroscopy (GC-MS) } \\
\text { and disc diffusion method. The result of this research was obtained essential oil with } \\
\text { pale yellow in colour paste-like typical odor with rendement of } 0,024 \% \text { and refractive } \\
\text { index of } 1,569 \text { at } 25^{\circ} \mathrm{C} \text {. Gas Chromatography-Mass Spectrometer data show that the } \\
\text { essential oil of the roots Sida rhombifolia Linn contains mainly } 2 \text { components: terpinen- } \\
4-\text { ol and } \alpha \text {-terpineol. The activity test on Escherichia coli bacteria in concentrations of } \\
750 \text { and } 1000 \text { ppm showed a retardation area of } 0,0176 \mathrm{~mm}^{2} \text { dan } 0,0197 \mathrm{~mm}^{2} \text { in wide, in } \\
\text { concentrations of } 750 \text { and } 1000 \text { ppm it retarded Staphylococcus aureus bacteria to a wide } \\
\text { of } 0,0123 \mathrm{~mm}^{2} \text { and } 0,0158 \mathrm{~mm}^{2} \text {. }\end{array}$ \\
\hline
\end{tabular}

\section{Abstrak}

Kata kunci: antibakteri, minyak atsiri, Sida rhombifolia Linn.
Telah dilakukan penelitian tentang isolasi, identifikasi dan uji aktivitas antibakteri minyak atsiri akar sidaguri (Sida rhombifolia Linn). Penelitian ini bertujuan untuk mengisolasi, mengidentifikasi senyawa minyak atsiri dari akar sidaguri serta mengetahui aktivitasnya sebagai antibakteri. Metode yang dilakukan dalam penelitian ini meliputi destilasi uap, brine shrimp lethality test (BSLT), Kromatografi GasSpektrometer Massa (GC-MS) dan metode difusi cakram kertas. Dari hasil penelitian diperoleh minyak berwarna kuning muda berbentuk seperti pasta yang berbau khas sidaguri dengan rendemen $0,024 \%$ dan indeks bias sebesar 1,569 pada $25^{\circ} \mathrm{C}$. Analisis Kromatografi Gas-Spektrometer Massa (GC-MS) menunjukkan bahwa minyak atsiri akar sidaguri didominasi oleh 2 senyawa: 4-terpineol dan $\alpha$-terpineol. Hasil uji aktivitas minyak atsiri terhadap bakteri Escherichia coli pada konsentrasi 750 ppm dan 1000 ppm menunjukkan luas daerah hambatan sebesar 0,0176 $\mathrm{mm} 2$ dan 0,0197 $\mathrm{mm} 2$, sedangkan minyak atsiri pada bakteri Staphylococcus aureus sebesar 0,0123 mm2 dan 0,0158 mm2.:

\section{Pendahuluan}

Tumbuh-tumbuhan dimanfaatkan sebagai bahan baku obat oleh berbagai bangsa sejak ribuan tahun yang lalu. Semakin meningkatnya kebutuhan akan obatobatan maka perlu dilakukan penelitian mengenai senyawa aktif yang ada pada tumbuhan obat tersebut serta pengaruhnya sebagai obat, sehingga perlu dilakukan upaya pengenalan, penelitian, pengujian dan pengembangan khasiat dan keamanan suatu tumbuhan obat [1].

Usaha penggalian sumber-sumber minyak atsiri dewasa ini semakin meningkat seiring dengan 
kemajuan teknologi di bidang minyak atsiri. Minyak atsiri dari beberapa tumbuhan diketahui bersifat aktif biologis sebagai antibakteri dan antijamur [2]. Minyak atsiri tersebut diambil dari berbagai jenis tanaman penghasil minyak atsiri [3].

Salah satu tumbuhan yang telah lama dipergunakan oleh masyarakat Indonesia sebagai bahan obat-obatan adalah sidaguri (Sida rhombifolia L.). Tumbuhan sidaguri khususnya bagian akar sering dipergunakan sebagai obat diare. Akar sidaguri mengandung alkaloid, steroid, minyak atsiri dan efedrine [4]. Berbagai penelitian telah dilakukan untuk menyelidiki manfaat dari tumbuhan sidaguri. Sidaguri dilaporkan memiliki aktivitas anti inflamasi [5]. Islam, dkk. [6] melaporkan adanya aktivitas larvasidal dari senyawa fenil etil-D glukopiranosida yang diisolasi dari ekstrak kloroform batang sidaguri. Andarini, dkk. [7] melaporkan adanya aktivitas antibakterial dari alkaloid daun sidaguri. Minyak atsiri daun sidaguri berpotensi sebagai pestisida [8].

Belum adanya publikasi tentang penelitian minyak atsiri dari akar sidaguri sebagai antibakteri, maka dalam penelitian ini dilakukan isolasi minyak atsiri dari akar sidaguri untuk mengetahui komponen senyawa minyak atsiri akar sidaguri, serta mengetahui aktivitas biologis dari minyak atsiri akar sidaguri sehingga diketahui potensi kegunaan dari minyak atsiri akar sidaguri tersebut.

\section{Metodologi}

Bahan

Akar sidaguri (diambil di sekitar perumahan Tembalang, Semarang, Jawa Tengah), natrium sulfat anhidrat $\left(\mathrm{Na}_{2} \mathrm{SO}_{4}\right)$, telur udang Artemia salina, garam krosok, aquades, larutan tween-20, alkohol $70 \%$, spiritus, cakram kertas diameter $6 \mathrm{~mm}$, Nutrien Broth (NB), Nutrien agar (NA), tetrasiklin, biakan bakteri gram-negatif Eschericia coli dan biakan bakteri grampositif Staphylococcus aureus.

\section{Alat}

Seperangkat alat destilasi uap, timbangan analit, kertas saring, aluminium foil, peralatan gelas, statif dan klem, kapas, tissue, refraktometer, seperangkat alat analisis GC-MS, akuarium kecil, lampu neon, penjepit, cawan petri (petri dish), botol semprot, lampu bunsen, autoklaf klinis, inkubator, inkubator bergoyang (shaker), inokulum, penggaris, jarum ose, sprider dan mikropipet.

\section{Cara Kerja}

\section{Preparasi Sampel}

Akar sidaguri (Sida rhombifolia L.) dicuci, dipotong dan dikeringkan pada suhu kamar sehingga diperoleh simplisia sidaguri.

\section{Isolasi Minyak Atsiri dengan Metode Destilasi Uap}

Sebanyak 4,75 kg akar sidaguri kering didestilasi dengan metode destilasi uap sebanyak 10 kali. Sekali destilasi dilakukan selama empat jam. Setelah proses destilasi selesai, destilat yang terbentuk didiamkan sampai terpisah menjadi 2 lapisan, lapisan atas adalah minyak dan lapisan bawah adalah air. Lapisan atas diambil kemudian ditambahkan dengan natrium sulfat anhidrat, sehingga didapat minyak atsiri yang bebas air.

\section{Sifat-sifat Fisik dari Minyak Atsiri}

Kriteria yang digunakan untuk menentukan mutu dan kemurnian dari minyak atsiri meliputi: warna, bau, dan indeks bias. Indeks bias minyak sidaguri diukur menggunakan refraktometer.

\section{Identifikasi Senyawa Minyak Atsiri}

Komponen-komponen senyawa minyak atsiri dianalisis menggunakan alat GC-MS untuk menentukan struktur molekul senyawanya.

\section{Uji Toksisitas}

Uji toksisitas dilakukan untuk menentukan aktivitas senyawa-senyawa minyak atsiri daun sidaguri.

\section{Uji Aktivitas Antibakteri}

Sterilisasi alat dan bahan. Cawan petri, jarum ose, penjepit, spatula dan erlenmeyer dicuci, dikeringkan dan dibungkus dengan kertas. Kemudian paper dish, media Nutrient Broth (NB), Nutrient Agar (NA) dan seluruh alat yang telah dibungkus kertas (kecuali larutan minyak atsiri akar sidaguri dan senyawa antibiotik) disterilisasi di dalam autoklaf selama 20 menit pada suhu $121^{\circ} \mathrm{C}[9]$.

Regenerasi Bakteri. Sebelum dipakai untuk pengujian, bakteri yang akan dipakai diregenerasi terlebih dahulu. Langkah yang dilakukan adalah membuat biakan agar miring yaitu menggoreskan biakan dari stok bakteri ke media Nutrient Agar (NA) miring dalam tabung reaksi. Kemudian diinkubasi pada suhu $37^{\circ} \mathrm{C}$ selama 24 jam. Dari biakan tersebut diambil satu mata ose bakteri dan diinokulasikan ke erlenmeyer yang berisi $100 \mathrm{~mL}$ media Nutrient Broth (NB) steril. Erlenmeyer tersebut diinkubasi di dalam inkubator bergoyang (shake) selama 24 jam [10].

Pengujian Antibakteri. Bakteri untuk uji aktivitas antibakteri ini adalah Eschericia coli (gram negatif) dan Staphylococcus aureus (gram positif). Pelaksanaan uji aktivitas antibakteri ini dilakukan dengan metode difusi cakram kertas. Minyak atsiri akar sidaguri diuji dengan konsentrasi berbeda terhadap pertumbuhan bakteri Staphylococcus aureus dan Eschericia coli. Cawan petri yang berisi media Nutrient Agar yang telah disterilisasi dan memadat diberi suspensi bakteri sebanyak $50 \mu \mathrm{L}$ dan diratakan dengan menggunakan spreader. Setelah itu cakram kertas dengan diameter $6 \mathrm{~mm}$ yang telah dicelupkan ke dalam larutan ekstrak minyak atsiri akar sidaguri masing-masing dengan konsentrasi 500 ppm, $750 \mathrm{ppm}$ dan $1000 \mathrm{ppm}$ diletakkan pada permukaan media NA yang telah diinokulasi suspensi bakteri. Cawan petri diinkubasikan dengan cara terbalik selama 24 jam pada suhu $37^{\circ} \mathrm{C}$ [9]. Daerah bening di sekitar kertas cakram menunjukkan uji positif, diameter daerah bening yang diperoleh kemudian diukur menggunakan penggaris. Larutan tween-20 $100 \mu \mathrm{L}$ dalam $10 \mathrm{~mL}$ 
aquades digunakan sebagai kontrol negatif, sedangkan untuk kontrol positif digunakan tetrasiklin $100 \mathrm{ppm}$.

\section{Hasil dan Pembahasan}

\section{Isolasi Minyak Atsiri Akar Sidaguri}

Minyak atsiri murni yang diperoleh dari 4,75 kg akar sidaguri kering adalah 1,6 mL yang kemudian ditimbang dan didapatkan 1,1630 g, sehingga diperoleh rendemen sebesar 0,024\%. Minyak atsiri akar sidaguri berwarna kuning muda, berbentuk pasta pada suhu kamar dan berbau khas sidaguri. Pengukuran dengan refraktometer menghasilkan indeks bias sebesar 1,569 . Menurut penelitian [11] indeks bias minyak atsiri sidaguri sebesar 1,469. Perbedaan nilai indeks bias mungkin disebabkan oleh perbedaan varietas dan perbedaan asal tumbuhan yang menyebabkan perbedaan komposisi minyak. Hasil analisis dengan GCMS dipaparkan pada gambar 1.

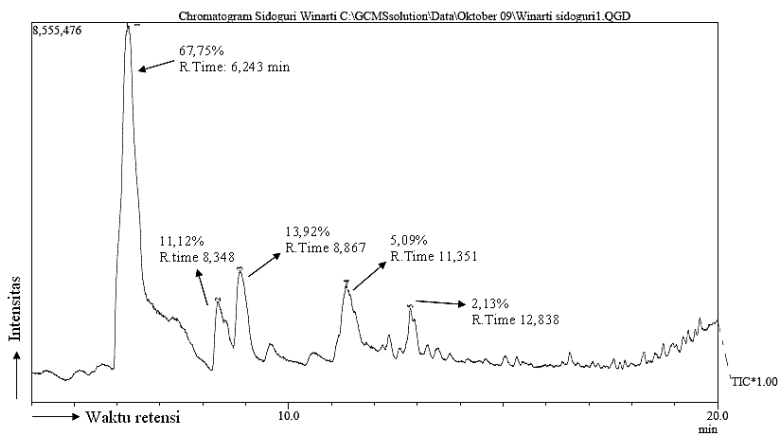

Gambar 1. Kromatogram GC
Dari analisis dengan GC-MS diperoleh 5 puncak. Senyawa yang diidentifikasi adalah senyawa dengan nomor puncak 2 dan 3. Puncak nomor 1, 4 dan 5 tidak diidentifikasi lebih lanjut karena setelah dibandingkan antara spektrum massa senyawa yang diperoleh dengan spektrum massa dari data base menunjukkan adanya ketidaksamaan puncak-puncak. Analisis dengan spektrometer massa menunjukkan bahwa spektrum massa senyawa puncak 2 dengan waktu retensi 8,348 menit, kelimpahan 11,12 \% ditampilkan pada gambar 2.a, sedangkan spektrum massa senyawa dari pusat data base GC-MS yang memiliki kemiripan $94 \%$ dengan spektrum massa puncak nomor 2 ditampilkan pada gambar 2.b.

Tampak pada gambar 2.a., spektrum massa senyawa puncak nomor 1 mirip dengan gambar 2.b. yang merupakan spektrum massa dari 4-terpineol. Senyawa 4-terpineol merupakan golongan senyawa terpenoid yaitu termasuk monoterpen dengan berat molekul 154, memiliki fragmentasi dengan m/e: 41,43, 69, 71 (base peak), 93, 111, 112, 136 dan 154. Rumus molekul senyawa 4-terpineol $\mathrm{C}_{10} \mathrm{H}_{18} \mathrm{O}$ dengan rumus struktur sebagai berikut:<smiles>CC1=CCC(O)(C(C)C)CC1</smiles>

Gambar 3. Senyawa 4-terpineol

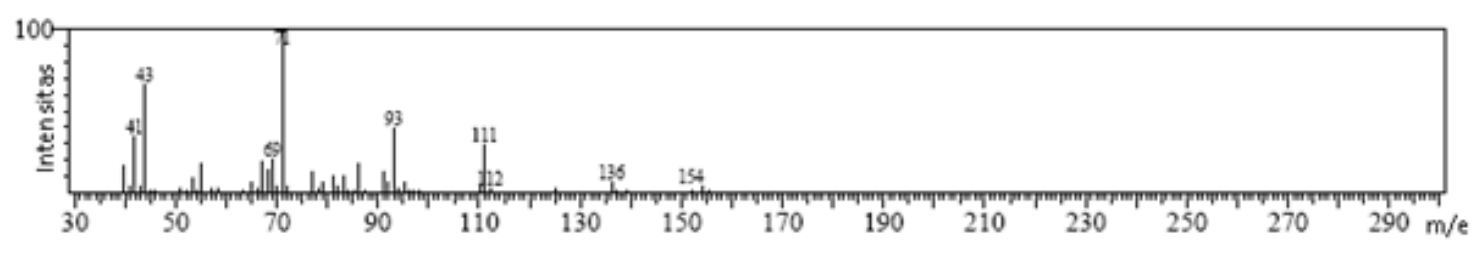

Gambar 2.a. Spektrum Massa Puncak 2

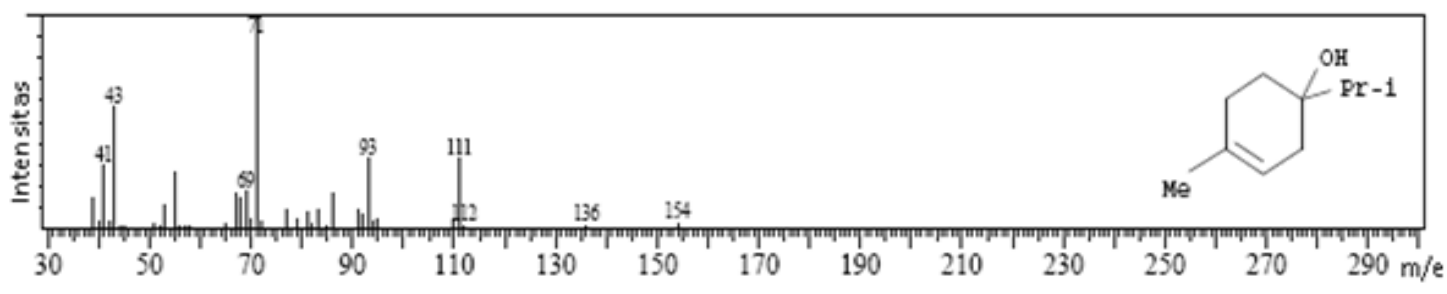

Gambar 2.b. Spektrum Massa 4 - terpineol

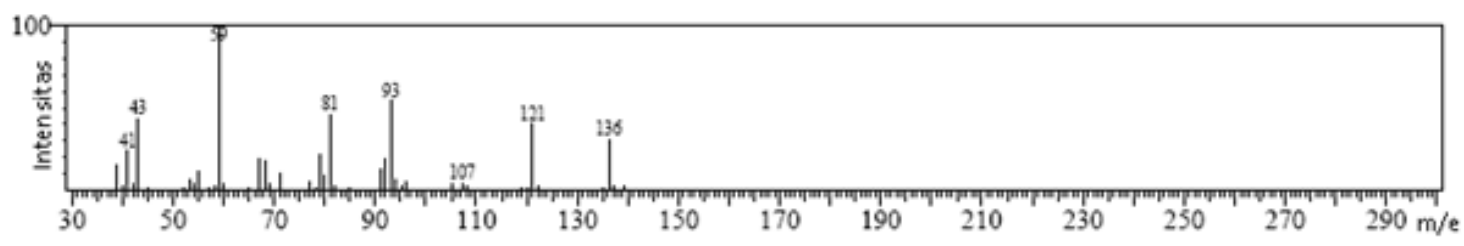

Gambar 4.a. Spektrum Massa Puncak 3 


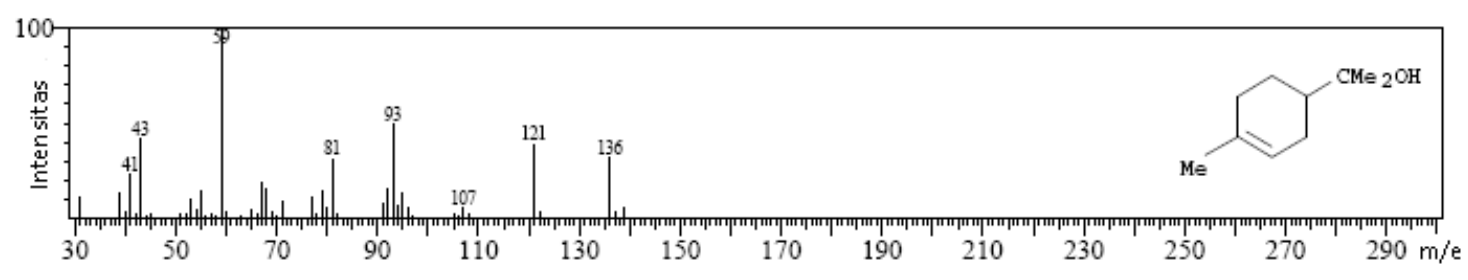

Gambar 4.b. Spektrum Massa $\alpha$-terpineol

Analisis dengan spektrometer massa menunjukkan bahwa spektrum massa puncak 3 dengan waktu retensi 8,867 menit, kelimpahan 13,92 \% ditampilkan pada gambar 4.a., sedangkan spektrum massa senyawa dari pusat data base GC-MS yang memiliki kemiripan $94 \%$ dengan spektrum massa puncak nomor 7 ditampilkan pada gambar 4.b.

Tampak pada gambar 4.a., spektrum massa senyawa puncak nomor 3 mirip dengan gambar 4.b. yang merupakan struktur $\alpha$-terpineol. Senyawa $\alpha-$ terpineol merupakan golongan senyawa terpenoid yaitu termasuk golongan monoterpen dengan berat molekul 154, memiliki fragmentasi dengan m/e: 41, 43, 59 (base peak), 81, 93, 107, 121 dan 136. Rumus molekul senyawa $\alpha$-terpineol $\mathrm{C}_{10} \mathrm{H}_{18} \mathrm{O}$ dengan rumus struktur sebagai berikut:<smiles>CC1=CCC(C(C)(C)O)CC1</smiles>

Gambar 5. Senyawa $\alpha$-terpineol

Untuk mempermudah pengkajian kandungan senyawa minyak atsiri akar sidaguri, komponen kimia dari minyak atsiri minyak atsiri akar sidaguri disajikan dalam tabel 1.

Tabel 1. Kandungan kimiawi minyak atsiri akar sidaguri (Sida rhombifolia L.)

\begin{tabular}{|c|c|c|c|c|}
\hline $\begin{array}{l}\text { Nomor } \\
\text { Puncak }\end{array}$ & $\begin{array}{l}\text { Waktu } \\
\text { retensi } \\
\text { (menit) }\end{array}$ & $\begin{array}{c}\text { Berat } \\
\text { Molekul } \\
\text { (g/mol) }\end{array}$ & $\mathrm{m} / \mathrm{e}$ & Senyawa \\
\hline 2 & 8,348 & 154 & $\begin{array}{c}41,43,69,71 \\
\text { (base peak), 93, } \\
111,112,136 \text { dan } \\
154\end{array}$ & $\begin{array}{c}4^{-} \\
\text {terpineol }\end{array}$ \\
\hline 3 & 8,867 & 136 & $\begin{array}{c}41,43,59 \text { (base } \\
\text { peak), 81, 93, } \\
107,121 \text { dan } 136\end{array}$ & $\begin{array}{c}\alpha- \\
\text { terpineol }\end{array}$ \\
\hline
\end{tabular}

Perhitungan dengan program probit analysis diperoleh harga LC $_{50}$ sebesar 199,848 ppm. Menurut Meyer, $d k k$. [12] apabila nilai $\mathrm{LC}_{50} 0-30 \mathrm{ppm}$, senyawa atau ekstrak bersifat sitotoksik dan mempunyai aktivitas sebagai antikanker, nilai $\mathrm{LC}_{50}$ 30-200 ppm mempunyai aktivitas sebagai antibakteri, sedangkan nilai LC $_{50}$ 200-1000 ppm mempunyai aktivitas sebagai pestisida, sehingga dapat disimpulkan minyak atsiri akar sidaguri hasil isolasi berpotensi sebagai antibakteri. Hasil uji BSLT dipaparkan pada tabel 2.
Tabel 2. Hasil uji BSLT minyak atsiri akar sidaguri, dengan jumlah hewan uji 10 ekor/sampel

\begin{tabular}{|c|c|c|c|c|}
\hline \multirow{2}{*}{ Konsentrasi } & \multirow{2}{*}{$\sum$} & \multicolumn{3}{|c|}{ larva artemia salina mati } \\
\hline & & II & III & Kontrol \\
\hline $1000 \mathrm{ppm}$ & 9 & 8 & 8 & 1 \\
\hline $100 \mathrm{ppm}$ & 4 & 3 & 4 & 0 \\
\hline $10 \mathrm{ppm}$ & 0 & 1 & 1 & 0 \\
\hline Harga $\mathrm{LC}_{50}$ & \multicolumn{4}{|c|}{$199,848 \mathrm{ppm}$} \\
\hline
\end{tabular}

\section{Uji Aktivitas Antibakteri}

Uji aktivitas antibakteri ini dilakukan untuk mengetahui aktivitas antibakteri minyak atsiri akar sidaguri. Pengujian aktivitas antibakteri dilakukan terhadap bakteri gram negatif Eschericia coli dan bakteri gram positif Staphylococcus aureus. Alasan penggunaan kedua bakteri tersebut adalah sebagai pembanding, karena bakteri dikelompokkan secara garis besar berdasarkan susunan dinding selnya menjadi 2 yaitu bakteri gram negatif dan gram positif [9]. Selain itu, alasan penggunaan kedua bakteri tersebut adalah karena kedua bakteri tersebut merupakan bakteri yang dapat merugikan manusia dalam kehidupan sehari-hari. Bakteri Eschericia coli, meskipun merupakan flora usus normal pada manusia namun dapat menyebabkan diare [13]. Bakteri Staphylococcus aureus dapat merusak produk daging dan ikan dan jika terkonsumsi oleh manusia efek negatifnya adalah penyakit radang mukosa usus [13].

Metode yang digunakan dalam uji antibakteri ini adalah metode cakram kertas. Digunakan metode ini karena metode ini paling umum, mudah dan sederhana untuk menentukan aktivitas antibakteri terhadap sampel yang diuji. Cakram kertas yang digunakan memiliki diameter $6 \mathrm{~mm}$. Dalam pengujian antibakteri ini, sebagai kontrol positif uji antibakteri digunakan antibiotik tetrasiklin. Dipilih tetrasiklin sebab tetrasiklin telah teruji kemampuannya sebagai antibakteri dan memiliki spektrum antibakteri yang luas karena mempunyai kemampuan untuk menghambat pertumbuhan bakteri gram positif maupun bakteri gram negatif. Dalam penelitian ini digunakan konsentrasi tetrasiklin $100 \mathrm{ppm}$. Dalam penelitian ini digunakan konsentrasi tetrasiklin 100 ppm karena tetrasiklin merupakan senyawa yang telah murni dan telah teruji kemampuannya sebagai antibakteri.

Zona hambat yang diberikan oleh larutan tetrasiklin 100 ppm diharapkan memberikan uji positif dalam menghambat pertumbuhan bakteri sehingga dapat digunakan sebagai kontrol positif terhadap kemampuan 
minyak atsiri akar sidaguri dalam menghambat pertumbuhan bakteri Eschericia coli dan Staphylococcus aureus. Perlakuan kontrol negatif berupa larutan Tween20 yang digunakan sebagai pelarut tidak memberikan hambatan terhadap pertumbuhan bakteri Eschericia coli dan Staphylococcus aureus. Hal ini menegaskan bahwa zona hambat yang terbentuk dalam pengujian aktivitas antibakteri minyak atsiri akar sidaguri bukan disebabkan oleh pelarut yang digunakan sebagai pengencer melainkan disebabkan oleh senyawa yang terkandung di dalam minyak atsiri akar sidaguri. Hasil uji aktivitas antibakteri minyak atsiri akar sidaguri dapat dilihat pada tabel 3.

Tabel 3. Luas daerah hambatan pertumbuhan bakteri oleh minyak atsiri akar sidaguri

\begin{tabular}{|c|c|c|c|}
\hline \multirow[b]{2}{*}{ No } & \multirow[b]{2}{*}{ Ekstrak } & \multicolumn{2}{|c|}{ Spesies bakteri } \\
\hline & & $\begin{array}{l}\text { Escherichia } \\
\text { coli }\left(\mathrm{mm}^{2}\right)\end{array}$ & $\begin{array}{l}\text { Staphylococcus } \\
\text { aureus }\left(\mathrm{mm}^{2}\right)\end{array}$ \\
\hline 1. & $\begin{array}{l}\text { Kontrol negatif } \\
\text { (Tween-20 + } \\
\text { aquades) }\end{array}$ & 0 & 0 \\
\hline 2. & $\begin{array}{l}\text { Kontrol positif } \\
\text { (Tetrasiklin } 100 \\
\text { ppm) }\end{array}$ & 224,6463 & 211,56 \\
\hline 3. & $\begin{array}{l}\text { Minyak Atsiri } 500 \\
\text { ppm }\end{array}$ & 0 & 0 \\
\hline 4. & $\begin{array}{l}\text { Minyak Atsiri } 750 \\
\text { ppm }\end{array}$ & 0,0176 & 0,0123 \\
\hline 5. & $\begin{array}{l}\text { Minyak Atsiri } 1000 \\
\text { ppm }\end{array}$ & 0,0197 & 0,0158 \\
\hline
\end{tabular}

Tabel 3 menunjukkan bahwa minyak atsiri akar sidaguri pada konsentrasi 500 ppm belum dapat menghambat pertumbuhan bakteri Escherichia coli dan Staphylococcus aureus, sedangkan pada konsentrasi 750 ppm sudah dapat menghambat pertumbuhan kedua bakteri yang diuji yaitu $0,0176 \mathrm{~mm}^{2}$ pada bakteri Escherichia coli dan $0,0123 \mathrm{~mm}^{2}$ pada bakteri Staphylococcus aureus. Minyak atsiri pada konsentrasi 1000 ppm menghambat pertumbuhan bakteri Escherichia coli dan Staphylococcus aureus dengan luas daerah hambatan masing-masing $0,0197 \mathrm{~mm}^{2}$ dan $0,0158 \mathrm{~mm}^{2}$. Hasil uji antibakteri menunjukkan bahwa minyak atsiri akar sidaguri memiliki aktifitas antibakteri meskipun sangat kecil. Dari hasil uji aktivitas ini, konsentrasi 500 ppm belum dapat menghambat kedua bakteri yang diuji, diduga senyawa yang terkandung dalam minyak atsiri konsentrasi 500 ppm sedikit sehingga minyak atsiri tidak aktif terhadap bakteri Escherichia coli dan Staphylococcus aureus. Hasil penelitian uji aktivitas bakteri minyak atsiri akar sidaguri pada konsentrasi 750 ppm dan 1000 ppm menunjukkan bahwa luas daerah hambatan bertambah dengan bertambahnya konsentrasi. Konsentrasi minyak atsiri akar sidaguri semakin tinggi maka bahan aktif yang terkandung di dalamnya semakin banyak, akibatnya pertumbuhan bakteri juga akan semakin dihambat. Bila dibandingkan senyawa standar (antibiotik tetrasiklin) terlihat bahwa minyak atsiri akar sidaguri menunjukkan aktivitas yang jauh lebih rendah, hal ini disebabkan banyaknya komponen senyawa kurang aktif pada minyak atsiri akar sidaguri. Minyak atsiri bukanlah senyawa tunggal tetapi gabungan dari beberapa senyawa dengan gugus fungsi yang berbeda-beda.

Hasil penelitian menunjukkan bahwa minyak atsiri akar sidaguri mampu menghambat pertumbuhan bakteri Escherichia coli dan Staphylococcus aureus. Pengamatan hasil uji aktivitas antibakteri menunjukkan bahwa kemampuan minyak atsiri akar sidaguri dalam menghambat pertumbuhan bakteri terbatas pada waktu tertentu. Pengamatan pada waktu inkubasi 8 jam, zona hambat terlihat bening seluruhnya, tetapi pada pengamatan waktu inkubasi 24 jam, di bagian terluar zona hambat terlihat keruh, artinya bakteri dapat tumbuh meskipun pada daerah yang terdapat minyak atsiri akar sidaguri. Dari pengamatan tersebut, disimpulkan minyak atsiri akar sidaguri hanya mampu menghambat pertumbuhan bakteri Escherichia coli dan Staphylococcus aureus atau disebut juga bersifat bakteriostatik.

Uji aktivitas antibakteri minyak atsiri akar sidaguri menunjukkan hasil yang berbeda. Hasil penelitian menunjukkan bahwa minyak atsiri akar sidaguri lebih kuat menghambat pertumbuhan bakteri gram negatif dibandingkan bakteri gram positif. Untuk dapat membunuh bakteri, minyak atsiri harus masuk ke dalam sel melalui dinding sel. Proses perakitan dinding sel bakteri diawali dengan pembentukan rantai peptida yang akan membentuk jembatan silang peptida yang menggabungkan antara rantai glikan dari peptidoglikan sehingga menyebabkan dinding sel terakit sempurna. Jika ada hambatan dalam pembentukannya, maka sel bakteri akan mengalami lisis yang kemudian diikuti dengan kematian sel. Diperkirakan minyak atsiri akar sidaguri mampu mengganggu perakitan rantai peptida pada peptidoglikan penyusun dinding sel bakteri, sehingga lebih mudah mengalami lisis. Tanpa dinding sel, bakteri tidak dapat bertahan terhadap pengaruh luar dan segera mengalami kematian.

Dinding sel bakteri gram positif (Staphylococcus aureus) mempunyai rantai peptida yang tersusun rapat dan beraturan antara rantai glikan yang satu dengan yang lain, sehingga menyebabkan struktur dinding selnya menjadi lebih sulit untuk dirusak. Meskipun lebih sulit untuk ditembus senyawa dari luar, diprediksikan larutan minyak atsiri akar sidaguri mampu merusak rantai peptida yang menyusun peptidoglikan, sehingga dinding sel bakteri menjadi lemah dan mengalami lisis. Dinding sel bakteri gram negatif (Escherichia coli), rantai peptidanya tersusun kurang beraturan dan tidak rapat antara rantai glikan yang satu dengan yang lain, sehingga minyak atsiri akar sidaguri akan lebih mudah menembus dinding sel bakteri Escherichia coli. Terjadinya perbedaan tekanan osmotik di dalam dan luar sel menyebabkan nutrisi yang seharusnya dibutuhkan oleh sel akan keluar. Kekurangan nutrisi menyebabkan pembentukan dinding sel akan terhalangi yang selanjutnya akan menyebabkan kematian sel.

Dinding sel pada bakteri gram positif (Staphylococcus aureus) terdiri atas peptidoglikan yang sangat tebal sehingga lebih sulit untuk ditembus senyawa dari luar 
sedangkan pada bakteri gram negatif (Escherichia coli), lapisan peptidoglikan pada dinding selnya tipis, sehingga lebih mudah untuk ditembus senyawa dari luar. Pada bakteri gram negatif, lapisan peptidoglikan pada dinding selnya tipis dan dikelilingi lipoprotein, lipopolisakarida (LPS), fosfolipid dan beberapa protein [14]. Jika diuraikan, LPS mempunyai struktur Lipid A dan polisakarida. Polisakarida membentuk ikatan hidrogen dengan gugus $\mathrm{OH}$ pada senyawa aktif minyak atsiri kemudian menghalangi aliran nutrisi, sehingga bakteri akan mati karena kehabisan nutrisi. Senyawa aktif yang terkandung dalam minyak atsiri akar sidaguri adalah senyawa 4-terpineol dan $\alpha$-terpineol.<smiles>CC1=CCC(O)(C(C)C)CC1</smiles>

4 -terpineol<smiles>CC1=CCC(C(C)(C)O)CC1</smiles>

$\alpha$-terpineol

Gambar 6. Senyawa aktif 4-terpineol dan $\alpha$-terpineol

Mekanisme reaksi ikatan ikatan hidrogen antara gugus - $\mathrm{OH}$ dengan polisakarida ditunjukkan oleh gambar 7.

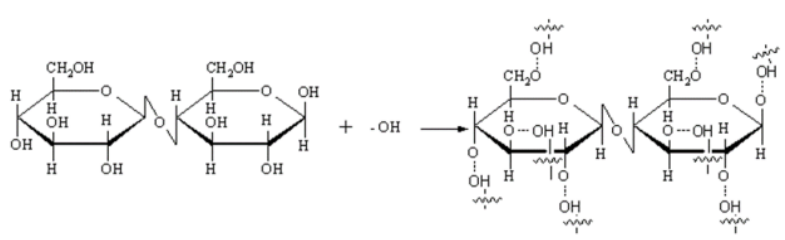

Gambar 7. Mekanisme reaksi ikatan hidrogen antara gugus - $\mathrm{OH}$ dengan polisakarida

\section{Kesimpulan}

Isolasi minyak atsiri dari akar sidaguri (Sida rhombifolia Linn) dengan metode destilasi uap yang diperoleh berwarna kuning muda berbentuk pasta berbau khas sidaguri dengan rendemen 0,024\% dan indeks bias $1,569\left(25^{\circ} \mathrm{C}\right)$. Hasil analisis dengan GC-MS menunjukkan minyak atsiri akar sidaguri mengandung komponen 4-terpineol (11,12 \%) dan $\alpha$-terpineol (13,92 $\%)$. Minyak atsiri akar sidaguri pada konsentrasi 750 ppm dan 1000 ppm aktif menghambat pertumbuhan bakteri Escherichia coli dengan luas daerah hambatan sebesar 0,0176 mm2 dan 0,0197 $\mathrm{mm} 2$, sedangkan terhadap bakteri Staphylococcus aureus sebesar 0,0123 $\mathrm{mm} 2$ dan 0,0158 mm2.

\section{Daftar Pustaka}

[1] Yuharmen, Yum Eryanti, Nurbalatif, Uji Aktivitas Antimikroba Minyak Atsiri dan Ekstrak Metanol Lengkuas (Alpinia galanga), in, Jurusan Kimia, FMIPA, Universitas Riau, 2002.

[2] P Aureli, A Costantinf, S Zolea, Antimicrobial activity of some plant essential oils against Listeria monocytogenes, Journal of Food Protection ${ }^{\circledR}$, 55 (1992) 344-348.

[3] Bulan Rumondang, Esterifikasi Patchouli Alkohol Hasil Isolasi Dari Minyak Daun Nilam (Patchoulli
Oil), in, Jurusan Kimia, Fakultas Matematika dan Ilmu Pengetahuan Alam, Universitas Sumatera Utara, Medan, 2004.

[4] Arief Hariana, 262 Tumbuhan Obat dan Khasiatnya, Penebar Swadaya, Jakarta, 2013.

[5] SA Dahanukar, RA Kulkarni, NN Rege, Pharmacology of medicinal plants and natural products, Indian Journal of Pharmacology, 32 (2000) 81-118.

[6] Md. Ekramul Islam, Naznin Ara Khatune, M. I. I. Wahed, Md. Ekramul Haque, Md. Ashiik Mosaddik Mosaddik, Larvicidal Activity of a New Glycoside, Phenyl Ethyl $\beta$-D Glucopyranoside from the Stem of the Plant Sida rhombifolia, Pakistan Journal of Biological Sciences, 6 (2003) 73-75.

[7] Faticha Dewi Andarini, Dewi Kusrini, Purbowatiningrum Ria Sarjono, Isolasi, Identifikasi dan Uji Aktivitas Antibakteri Alkaloid Total dari Daun Sidaguri (Sida rhombifolia Linn), in: Jurusan Kimia, Universitas Diponegoro, Semarang, 2009.

[8] Ferawati Kusuma, Dewi Kusrini, Enny Fachriyah, Isolasi, Identifikasi, dan Uji Toksisitas Minyak Atsiri Daun Sidaguri (Sida rhombifolia Linn), in: Jurusan Kimia, Universitas Diponegoro, Semarang, 2009.

[9] Michael J Pelczar, ECS Chan, Dasar-dasar mikrobiologi, Universitas Indonesia Press, Jakarta, 1988.

[10] M Hudayanti, Aktivitas Antibakteri Rimpang Temulawak (Curcuma xanthorrihza Roxb.), in: Jurusan Kimia, Institut Pertanian Bogor, Bogor, 2004 .

[11] Moghis U Ahmad, SK Husain, M Ahmad, SM Osman, R Subbarao, Cyclopropenoid fatty acids in seed oils ofSida acuta andSida rhombifolia (malvaceae), Journal of the American Oil Chemists' Society, 53 (1976) 698-699.

[12] BN Meyer, NR Ferrigni, JE Putnam, LB Jacobsen, DE j Nichols, Jerry L McLaughlin, Brine shrimp: a convenient general bioassay for active plant constituents, Planta medica, 45 (1982) 31-34.

[13] W Bibiana, S Hastowo, Mikrobiologi, Rajawali Pers, Jakarta, 1992.

[14] Usman Suwandi, Mekanisme Kerja Antibiotik, Cermin Dunia Kedokteran, (1992). 